\title{
THEORATICAL FRAMEWORK TO UNDERSTAND THE IMPACT OF ORGANIZATIONAL CHANGE ON THE ORGANIZATIONAL COMMITMENT
}

\author{
Kanika Sofat, Ravi Kiran \\ Research Scholar, School of Behaviroral Sciences and Business Studies, Thapar University, P.O. Box \\ 32, Patiala, Pin -147004, Punjab \\ kanikasofat@gmail.com \\ Professor and Head,School of Behaviroral Sciences and Business Studies, Thapar University, P.O. \\ Box 32, Patiala, Pin -147004, Punjab \\ rkiran@thapar.edu
}

ABSTRACT

\begin{abstract}
The organization change is defined as the adoption of new ideas or behavior by an organization. The main objective of organizational change is to maximize the benefits of the people involved in the process and to minimize the risk involved in the failure of implementing and managing change. Organization commitment of the employees is an intangible asset for an organization so as to derive strategic advantage over competitors. It is a psychological link between the employee and his organization. If the employees lack commitment it will lead to increase in absenteeism and affecting labor turnover. The commitment employees will hence ease stress during organizational change process and will understand and cope with change so as to make it successful. The paper helps to understand the organizational change initiatives undertaken in the organizations. It further helps to examine the relationship between change management and organization commitment in organizations.
\end{abstract}

Indexing terms/Keywords

Organizational change, Change levers, Organizational change initiatives, organization commitment

\section{Academic Discipline And Sub-Disciplines}

Human Resource Management,

\section{SUBJECT CLASSIFICATION}

Organizational Change Management

\section{TYPE (METHOD/APPROACH)}

\section{Conceptual study}

\section{Council for Innovative Research}

\section{Peer Review Research Publishing System}

Journal: Journal of Social Sciences Research

Vol .5, No.1

jssreditor.cir@gmail.com

www.jssronline.com 


\section{INTRODUCTION}

\section{Organizational Change}

"Every organization must change not only to survive but also to retain its relevance in a world of intense competition, constant scientific progress and rapid communication. But in order for change to bring a benefit and advance an organization at a higher level of service operation that change must be driven by knowledge"[9].

The organization change is defined as the adoption of new ideas or behavior by an organization [12]. The organization hence to survive has to change in the era of competition. The main objective of organizational change is to maximize the benefits of the people involved in the process and to minimize the risk involved in the failure of implementing and managing change. The change should be well planned and implemented so as to ensure organizations continual survival. This will help organization to raise tangible benefits like improved competition, better financial gains, more customer satisfaction, and higher organization commitment and employee satisfaction. The organizational change is considered with the change in organization's strategy, technology, culture and structure aimed in changing the employee's attitude, value and behavior [13]

The change management in the organization can either be 'reactive' in which it is responding to the change in macro environment (external source of change) or 'proactive' i.e. initiating change to achieve desired goals(internal source of change). There are different methodologies and approaches adopted by managers in the organization to bring about change. The forces of change can either be from within or from outside the firm. The managers are hence responsible to monitor the events that require planned organizational response. The techniques for initiating change include designing the organization for creating, encouraging change events and establishing new endeavor teams. The last stage is finally implementing the change in the organization and managing resistance.

Resistance to change in organization is there when a proposed change in job design, structure or technology may lead to a real or perceived loss of power, prestige, pay or company benefits. The fear of personal loss is perhaps the biggest obstacle to organizational change [38]. Resistance is also when employees do not understand the intended purpose of change, when previous working relationship with champion or change agent have been negative and is also due to uncertainty among employees when they do not know how change will affect them and they about situations whether they will be able to meet the demands of new product or technology [1]. Another reason for resistance to change is that people who will be affected by innovation may assess the situation differently from an idea champion or new- venture group. These reasons for resistance to change are legitimate in the eyes of employees affected by change. Managers as a result should not ignore resistance to change but should diagnose the reasons and design strategies to gain acceptance by users Deschamps [34].

\section{Organization Commitment}

Organization commitment of the employees is an intangible asset for an organization so as to derive strategic advantage over competitors. it is a psychological link between the employee and his organization [22]. The commitment of employees helps to influence the sustainable growth \& development of an organization, where the employees' attitude \& behavior have a strong bearing on customer loyalty. The organization commitment can be also defined as "a result of individual organizational transactions and alternatives in side bets or investment over time" [21]. The commitment of employees is influenced by various factors like organizational characteristics, culture, organizational communication training, and various leadership styles, job stress and satisfaction etc. since the organization commitment is the "relative strength of an individuals' identification with and involvement in a particular organization" and if this association is positive it acts as a powerful mediator for both the employees and employer. This will help to hence generate high levels of personal and professional satisfaction and an increase in the overall efficiency of the organization [31].

To increase the commitment of employees in today's era of competition and technology the managers need to focus on the employees affected. This as a result has helped organizations to gain productive employee and the employee works in a construction that responds to his needs. The employees in the organizations should be motivated towards higher commitment, as their contribution towards the attainment of organizational goals will increase further [43]. Further the commitment in an organization is affected by four broad categories i.e. personal characteristics, role related characteristics, structural characteristics and work experiences [28]. The other characteristics are the role related characteristics such as job scope or challenge, role conflict and role ambiguity. These characteristics need to be in balance with each other so as to feel satisfied with what they are doing otherwise they feel dissatisfied [2]. The work experience characteristics also affect the commitment of an organization. The variables included in it are personal importance of an organization, positive attitude towards organization, social involvement, group norms etc [28] . These variables should be managed properly especially when change occurs and can be significantly impacted if change interfaces with positive experience.

The employees with higher commitment have positive outcome like increase in job satisfaction level, motivation and regularity in work [4], [13]. If the employees lack commitment it will lead to increase in absenteeism and affecting labor turnover. The commitment employees will hence ease stress during organizational change process and will understand and cope with change so as to make it successful [15], [35]. The committed employees further help in the improvement of quality and client centeredness, improvement of organizational communication and a larger willingness to accept change [49]. 


\section{Objectives of study}

1.To examine the organizational change initiatives undertaken in the organizations.

2. To examine the relationship between change management and organization commitment in organizations.

On the basis of review of literature we have proposed the following model to understand the relationship between organization change and organization commitment

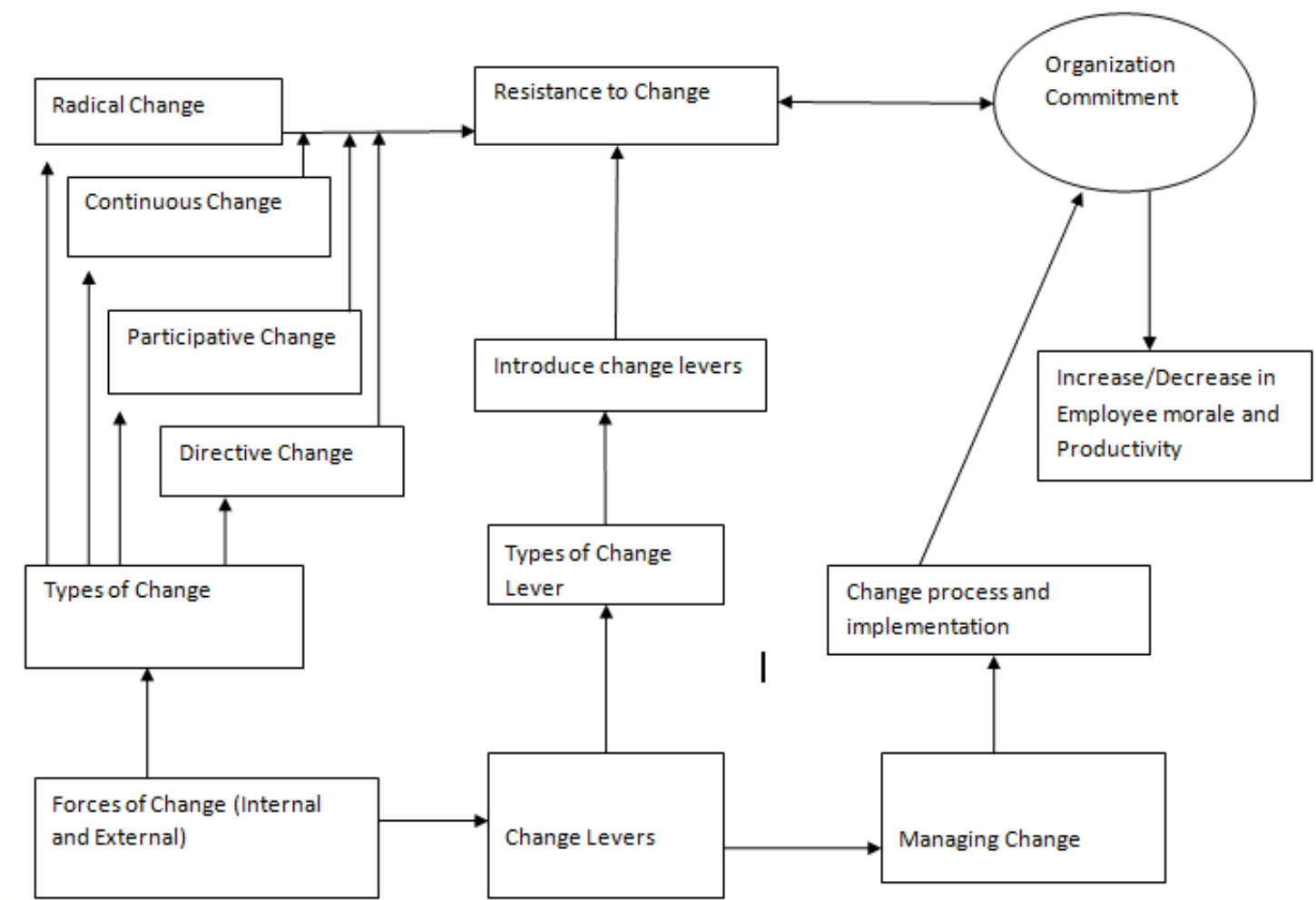

Figure 1: Conceptual Framework of impact of Organizational change on Organizational commitment

"Organizational change can be defined as any action or set of actions that result in a shift in direction or process that affect the way an organization works" [10]. The organizational change is the most important feature of an organizational lift at both operational and strategic level [7]. The change in an organization is present there in the past and is also necessary in future for forecasting. Any type of change occurring in the organizations has its impact on individuals, organizational, national and transnational levels [18]. These factors are also leads to resistance to change among the employees of the organization [27]. The change in organization occurs at three levels: at micro level where it concerns with changes that people face in their personal lives, at organization level it is associated with change in organization that impacts lives of people and last is at the macro level where change universally affects people and organizations.

\section{Forces of Change: its impact on Resistance and Organization Commitment:}

The organizations are affected by various internal and external factors of change. These forces directly or indirectly influence change in different forms. The external forces are the various external factors in the environment which directly or indirectly trigger change. It includes various factors like political, globalization \& liberalization, government policies, competition and changing customer preferences and markets. The internal factors are the ones operating within the organization that influence the change in the organization. The internal forces for change include system dynamics, managerial \& administrative processes, technological changes etc [17]. These forces usually move the organizations into a state of quasi stationary equilibrium [38]. Any factors in the environment that interferes with the organizations ability to attract the human financial and resources it needs or to produce and market its service/products becomes a force of change [18].

The organizations in order to deal with the impact of change forces has to plan, experience or undergo change. This helps the mangers to decide upon 'how to bring about necessary changes' in the organizations. As a result the managers need to be aware of different types of changes. The changes which refer to the overall nature of change process are the continuous or incremental change and discontinuous or radical change. The changes which refer to the way in which change process is brought about in the organization include participative and directive change [32] . According to Tushman \& Romanelli [46] these changes faced by the organizations lead to resistance to change as a result of sustained low performance, regardless of overall strategic orientation, change in technology, legal environment and competition. Another reason for resistance faced by employees in the organizations is due to their less involvement in planning and implementation process [50]. The stress, fear, anger and anxiety faced by employees in the overall change also leads to resistance[22]. This affects the psychological attachment of the employees with the organization. The resistance to 
change faced by the employees like in the case of radical change also affects the organizational commitment of employees[31]. the overall commitment at times is reduced caused by factors like job insecurity, increased stress, decreased trust and job redesign. [11], [14], [24].

\section{Change Levers: its impact on resistance to change \& organization commitment}

The organization change in the organizations should also answer 'What is to be changed?'. It constitutes various organizational factors or characteristics, events, activities or behaviors that help in the implementation of change [48]. These are also vitals for a change process and known as change levers [32], [33]. The change levers have three important contextual aspects for change i.e. Structure, Strategy and People Management. These aspects are important as they set context for change and help to make change process smooth. The rest four are the content areas i.e. technology, marketing, quality and cost. The last lever is 'Leadership' which is most important for the success of organizations. Any change in the content areas is accomplished by change in the contextual areas so as to make change permanent driven by value based leadership. Leadership is the most important lever in the success of change initiatives throughout change implementation process [20], [37], [44], [45] . Any change in organizational structure and processes and changes in HR practices are important change drivers leading to change and resistance to change [5], [30], [42]. The system change lever is useful to measure and assess change initiatives and take corrective actions towards change process and implementation [8].

The grouping of various HR practices like alignment of recruitment, selection, socialization of new employees and the behavioral system and processes help to sustain the momentum of organization change process and change implementation[6], [9]. The other change levers are also linked to sustain momentum of change implementation [30]. The change in organizational structure and processes is also helpful to reduce resistance to change by making the change real for the employees [34]. It is further useful for the successful implementation of change [23]. The other levers like leadership, change related communication and aligned structures are also linked to a number of organizational change processes and successful implementation of change in the organization [19], [25] . The right leadership approach is also important when managing changes in the change initiatives so as to overcome resistance to change as its outcome [3] and to bring successful change [40].

\section{Managing Change and its impact on Organization Commitment}

For the mangers in the organization another important issue regarding change is implementing change and managing resistance to change. The organizations at times underestimate the skills and capacity required to implement change, resulting in the change initiatives to be unsuccessful. The change initiative programmes are key tools to organizational long-term success [41]. The employees as a result should be encouraged to take part in the change program. According to Nilakant \& Ramnarayan [32] the discontinuous and continuous change requires different process of change to develop and evolve over time. The change process is defined as the process that deals with how the change is planned, launched, fully implemented and sustained after implementation [6]. The models of various authors like by Kurt Lewin [26] on unfreezing, moving and freezing can be used as change process and to implement change. Another approach by Nader, David \& Tushman [29] is on energizing, envisioning and enabling that can be used introduce and implement change. The model used to introduce and implement change depends upon the nature of change present in the organization. The major outcome faced by the organizations when introducing and implementing change or change process is 'resistance to change'. The resistance to change ultimately affects every aspect of the organization like commitment of the employees depending upon how they perceive the change [16]. The commitment of employees at times also decreases due to organizational change initiatives if not managed properly [47]. The commitment of employees is also affected due to internal and external factors resulting in at times improvement in quality, organization communication and willingness to change. The main reason behind it is the active participation and involvement of employees in the change process [31], [36].

\section{Conclusion}

The change in an organization is present there in the past and is also necessary in future for forecasting. Any type of change occurring in the organizations has its impact on individuals, organizational, national and transnational levels. The change in organization occurs at three levels: at micro level where it concerns with changes that people face in their personal lives, at organization level it is associated with change in organization that impacts lives of people and last is at the macro level where change universally affects people and organizations. The organization change has important aspects i.e. 'content of change', 'process of change' and its impact on the employees of the organization.

The major outcome faced by the organizations when managing organizational change initiatives is 'resistance to change'. The resistance to change ultimately affects every aspect of the organization like commitment of the employees depending upon how they perceive the change. The commitment of employees at times also decreases due to organizational change initiatives if not managed properly. The managers as a result should manage change properly and encourage on participation of employees during the change initiatives. This will ultimately lead to reduction in the level of employee resistance and have positive impact on the organization commitment.

\section{Reference for future work:}

The conceptual model is designed on the basis of a detailed study of the literature and previous studies. The future study should focus on the empirical research done in various industries to understand in more detail the impact of organizational change initiatives on the commitment of employees or on the other variables like job satisfaction, customer satisfaction, 
employee satisfaction etc. the first step in the process should be to carry out a detail analysis of the change initiatives in the selected industry on the basis of previous research. The second step should focus on understanding the impact on organizational change initiatives on the organizational commitment with the help of research tools. The suggestions and recommendations should also be stated based on the results of the study. The research could also be further divided on the basis of managerial hierarchy present in the organizations and understanding in detail steps taken by management to manage the change initiatives and overcoming resistance to change.

\section{REFERENCES}

[1] Apscar, L. M. (1985). Middle Management and Supervisors Resist Moves to More Participatory Management. The Wall Street Journal , 25.

[2] Allen, N., \& Meyer, J. (1990). The measurement and antecedents of affective, continuance and normative commitment yo the organization. Journal of Occupational Psychology , 1-18.

[3 ]Beckhard, R., \& Harris, R. (1897). Organizational Transitions:Managing Complex Change. Addison-Wesley.

[4] Benette, H., \& Durkin, M. (2000). The effect of organizational change on employee psychological attachment:An exploratory Study. Journal of Managerial Psychology Vol.15, 126-147.

[5] Bridges, W. (2003). Managing Transitions: Making the Most of Change, 2nd edn. Cambridge: MA: Perseus Publishing.

[6] Burke, W. (2008). Organization Change- Theory and Practice, 2nd end. Thousand Oaks: CA: Sage Publications Inc.

[7] Burnes, B. (2004). Managing Change: A strategic Approach to Organizational Dynamics, 4th Edition. Harlow:Prentice Hill.

[8] Cameron, E., \& Green, M. (2004). Making Sense of Change Management: A Complete Guide to the Models, Tools and Techniques of Organizational Change. London: Kogan Page.

[9] Charns, M. P. (1994). Implementing organizational change. [HSR\&D Newsletter](December), 2-3.

[10] Demarki, J. G. (2000). Organizational Change Primer. Health Services Research and Development Service Management Decision \& Research Centre .

[11] Dordevic, B. (2004). Employee commitment in times of Radical Change. Economics and Organization Vol. 2, No. 2 , 111-117.

[12] Daft, R. L. (2005). Types of Planned Change. In R. L. Daft, Management Sixth Edition (p. 387). Chennai: Thoman South Western.

[13] Gary, D. (2000). "Managing Organizational Renewal", Human Resource Mangaement. Prentice Hall International, Inc. 8th edition.

[14] Godkin, L. (2008). Overcoming Organizational Inertia:Atripartite Model for Achieving Strategic Organizational Change. Journal of Applied Business and Economics.

[15] Gomes, D. R. (2009). Organizational change and job satisfaction: the mediating role of organizational commitment. comunicacao eciencias empresariais , 177-196.

[16] Gravenhorst, K., Werkman, R., \& Boonstra, J. (2003). The Change Capacity of Organisations:General Assessment and Five Configurations. APPLIED PSYCHOLOGY: AN INTERNATIONAL REVIEW,52(1), 83-105.

[17] Harigopal. (2001). Management of Organziational Change. New Delhi: Response Books.

[18] Harigopal, K. (2006). Management of Organizational Change:Leveraging Transformation-2nd Edition. New Delhi: Response Books.

[19] Herold, D. M., Fedor, D. B., \& Caldwell, S. (2008). The Effects of Transformational and Change Leadership on Employees' Commitment to a Change: A Multilevel Study. Journal of Applied Psychology Vol. 93, No. 2 , 346-357.

[20] Hesselbein, F. (2002). The key to cultural transformation in :on Leading Change: A leader to leader guide. San Francisco: Jossey- Bass.

[21] Hrebiniak, L., \& Alutto, J. (1972). Personel and role related factors in the develpment of organizational commitment. Administrative Science Quarterly, Vol 17, 555-572.

[22] Inverson, R., \& Roy, P. (1994). A casual model of behavioural commitment: evidence from a study of Australian bluecollar employees. Journal of Management, Vol 20, No. 1, 15-41.

[23] Johnson, P., Cassell, C., Close, P., \& Duberley, J. (2001). Performance evalution and control: supporting organizational change. Management Decisions, 39(10) , 841-850.

[24] Judson, A. (1991). Changing behavior in organizations:Minizing resistance to change. B.Blackwell. 
[25] Karen, S., Whelan-Berry, \& Karen A., S. (2010). Linking Change Drivers and the organizational Change Process:A Review and Synthesis. Journal Of Change Mangement, Vol. 10, No.2 , 175-193.

[26] Lewin, K. (1947). Frontiers in Group Dynamics. Human Relations, Vol 1, 5-41.

[27] Mabin, V., Forgeson, S., \& Gren, L. (2001). Harnessing Resistance:using the theory of constraints to assist change management. Journal of European Industrial Training, Vol.25 , 168-191.

[28] Mowday, R., Porter, L., \& Steers, R. (1982). Employee-organization linkages:The psychology of commitment, absenteeism and turnover. NewYork: NY:Academic Press.

[29] Nader, David, \& Tushman. (1989). Organizational Framebending: Principles for Managing Reorientation. Academy of Management Executive, Vol. 3 , 194-202.

[30] Nadler, D., \& Tushman, M. (1990). Beyond the charismatic leader: leadership and organizational change. California Management Review , 77-97.

[31] Nijhof, W., Jong, M., \& Beukhof, G. (1998). Employee commitment in changing organizations:an exploration. Journal of European Industrial Training, Vol. 22, issue 6, 243 - 248.

[32] Nilakant, V., \& Ramnarayan, S. (2007). Managing Organizational Change. New Delhi: Response Books.

[33] Porras, J., \& Hoffer, S. (1996). Common behaviour changes in successful organization development efforts. Journal of Applied Behavioral Science,22(4) , 477-494.

[34] Recardo, R. (1995). Overcoming resistance to change. National Productivity Review, Spring , 5-12.

[35] Robbin, S., \& Langton, N. (2001). Organizational Behavior: Concepts, Controversies and Applications, 2nd ed. Toranto: Prentice Hall Inc.

[36] Ruiten, I. J. (December 2006 - September 2007). The influence of employee voice on organizational commitment in times of organizational change: An exchange perspective. Tilburg University: Masterthesis Human Resource Studies .

[37] Schein, E. (1992). Organziational Culture and Leadership, nd edn. San Francisco: Jossey-Bass.

[38] Schlesinger, J. a. (March- April 1979). Choosing Strategies for Change. Harward Business Review 57, $106-114$.

[39]Sharma, R. R. (2007). Change Management:Concepts and Applications. New Delhi: Tata McGraw Hill Publishing Company Limited.

[40] Simon-Elorza, K., Olazaranb, M., \& Albizuc, E. (2005). Reengineering and organizational change in irizar s. co-op. Total Quality Management \& Business Excellence, Vol 16 Iss.2 , 135-155.

[41] Soltania, E., Laib, P.-C., \& Mahmoudi, V. (2007). Managing Change Initiatives: Fantasy or Reality? The Case of Public Sector Organisations. Total Quality Management \& Business Excellence, Vol 18 Issue 1-2, 153-179.

[42] Somerville, K. (2009). The Key Drivers of Organizational Culture Change in the Public Sector:An Analysis of the Canadian Federal Government. Ottawa: Ontario: Library\& Canada.

[43] Sutano, E. (1999). The relationship between employee commitment and job performance http://puslit.petra.ac.id/journals/management/management01-01-99-5.htm .

[44] Taylor- Bianco, A., \& Schermerhorn, J. (2006). Self regulation, strategic leadership and paradox in organizational change. Journal of Change Management , 457-470.

[45] Trice, H., \& Beyer, J. (1991). Cultural leadership in organizations. Organization Science, 2(2) , 149-169.

[46] Tushman, M., \& Romanelli, E. (1985). Organizational Evolution: A Metamorphosis model of convergence and reorentation. Research in Organizational Behavior, Vol $7,172-222$.

[47] Visagie, C., \& Steyn, C. (2011). Organisational commitment and responses to planned organisational change: An exploratory study. Southern African Business Review Volume 15 Number 3, 98-121.

[48] Whelan-Berry, K., Gordon, J., \& Henings, C. (2003). The relative effect of change drivers in large scale organizational change:an empirical study, in: R. Woodman and W. Pasmore(eds). Research in Organizational Change and Development, Vlo. $14,99-146$.

[49] Wim J., N. M., \& Gijs, B. (1998). Employee commitment in changing organizations:an exploration. Journal of European Industrial Training, Vol.22 Iss:6 , 243-248.

[50] Young, A. (2000). I'm just me; a study of managerial resistance. Journal of Organizational Change Management, Vol 13, No4, 375-88. 


\section{Author' biography with Photo}

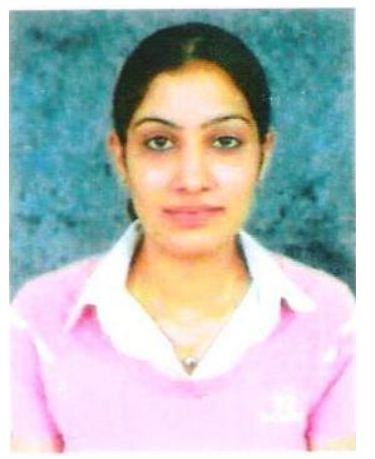

Kanika Sofat is working as guest faculty in University Institute of Applied Management Sciences, Panjab University. She is currently pursuing her PhD degree in change management. She has published papers in change management, HRM, TQM and organization commitment. Her current research focuses on the Information Technology sector of India.

[Author 2]
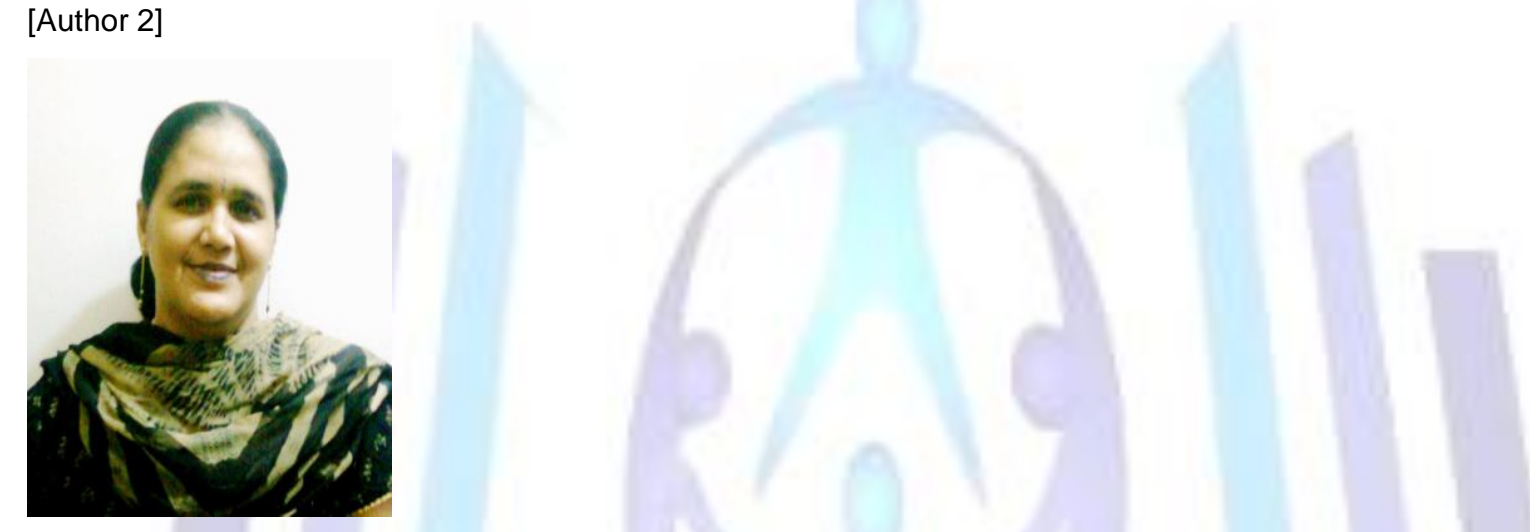

Ravi Kiran (PhD, Thapar University) is a head and professor of management at School of Behavioral Sciences and Business Studies, Thapar University. She has published papers in various national and international journals. Her areas of interOest include Industrial Management, Business Economics, Human Resource Development, IPRs \& E-Business. 